\title{
Suture Abrasion
}

National Cancer Institute

\section{Source}

National Cancer Institute. Suture Abrasion. NCI Thesaurus. Code C50868.

Wearing away of the surface of a suture as a result of bending and frictional forces. 